\title{
INVESTIGATION OF HYDROPOWER GENERATION FROM IRRIGATION DAMS
}

\author{
Recep BAKIŞ ${ }^{1,}$,, Yıldırım BAYAZIT ${ }^{2}$, Cengiz KOÇ ${ }^{3}$, Dost Mohammad AHMADY ${ }^{4}$ \\ ${ }^{1}$ Civil Engineering Department, Engineering Faculty, Anadolu University, Eskişehir, Turkey \\ ${ }^{2}$ Civil Engineering Department, Engineering Faculty, Bilecik Şeyh Edebali University, Bilecik, Turkey \\ ${ }^{3}$ City and Regional Planning Department, Architecture Faculty, Muğla Sitkı Koçman University, Muğla, Turkey \\ ${ }^{4}$ Civil Engineering Department, Engineering Faculty, Anadolu University, Eskişehir, Turkey
}

\begin{abstract}
Since geodetic and fossil energy that Turkey owns is insufficient and do not meet the demand, evaluation of renewable energy resource is very important for Turkey. For this reason, tending towards hydro-electric power is an applicable option and hydroelectric power is one of the most important energy resource for the country. From the point of view of water resources, evaluation of water potential of large and small streams for the purpose of energy production is vital for the country. Thereby, the existing deficit gap relevant to the energy, is reduceable.

Within this paper, Seydisuyu basin has been selected as the research area. Precipitation in the watershed is drained by Seydisuyu stream. Only two dams named as Kunduzlar and Çatören, were constructed and are currently in operation in the study area. These dams were built for the purposes of only irrigation and flood control, in the watershed. Water potential of the basin is very small, due to the slight amount of precipitation within that area. Accordingly, planning of only small-scale hydro-electric energy potential is considerable over these dams, for region/national economic advantage of the country. In this study, the hydro-electric power potential of these two existing dams, were investigated. For this purpose, using 19 years of monthly data obtained from six existing flow gauging stations in the basin, the amount of hydroelectric energy generation of these dams was analyzed individually. As the result of these analysis, the calculation of the annual energy production capacity, the installed power production, and the annual economic contribution for both Çatören and Kunduzlar dams were estimated as 4.14 GWh (2.15 GWh (Çatören) + 1.99 GWh (Kunduzlar)), 0.843 MW (0.273 MW (Çatören) + 0.57 MW (Kunduzlar)), and 495000 USD (257000 USD (Çatören) + 238000 USD (Kunduzlar)), respectively.
\end{abstract}

Keywords: Renewable energy, Hydro-electric power, Water resources, Water potential, Seydisuyu basin

\section{INTRODUCTION}

Energy is one of the basic representatives in the generation of prosperity and the basic indicator in the economic growth, not only for Turkey, but also other developing countries. Prompt rise of population and industrialization in the country has created a gross energy demand in recent years. The renewable energy is becoming increasingly popular, and hydropower has consistently been one of the most common type of renewable energy sources around the world, based on being inherent technical, clean, economical and compatible with the environmental [1]. However, water resource is not efficiently used in Turkey, the geographic region of Turkey is holding a major utility for extensive usage of hydropower energy sources. As Turkey has many streams applicable for energy generation, most of them are still unexploited [2]. On the other hand, existing growth rate is increasing the amount of energy need with each passing day. Development of renewable energy sources will play a significant role in the near future. For this reason, water resources must be evaluated ideally and energy need must be supplied most economically and productive in the country [3]. Therefore, in this study benefit of existing dams (Çatören and Kunduzlar Dams) that were constructed for other purposes like potable water supply,

*Corresponding Author: rbakis@anadolu.edu.tr

Receiving Date: 18 December 2017 Publishing Date: 29 June 2018 
domestic water supply, irrigation and flood control, but not for electricity in terms of hydroelectric generation, were discussed and investigated.

\section{STUDY AREA}

In this paper, Seydisuyu Basin was chosen as the study area. Seydisuyu basin is a sub-basin of Sakarya River, $12^{\text {th }}$ in number of the 26 major hydrological river basins in Turkey. Seydisuyu basin is located in the central Anatolia, Turkey, between $38^{\circ} 85^{\prime}-39^{\circ} 36^{\prime}$ north latitudes and $30^{\circ} 16^{\prime}-31^{\circ} 07^{\prime}$ east longitudes. Water of the watershed is discharged into Sakarya River by Seydisuyu river. Seydisuyu basin is surrounded by Sakarya-Sarısu, Porsuk-Sarısungur, Porsuk-Kalabak in the east, by Büyük Menderes, Gediz and Porsuk-Sarısungur in the southwest, and by Sakarya-Bardakçı and Akarçay basins in the southeast. As the hydrologic basin border, a great part of the basin is in the provincial borders of Eskişehir, and the remaining parts are in the provincial borders of Afyon and Kütahya. Seyitgazi, Mahmudiye districts of Eskişehir Kırka town and 51 villages are in the basin. Seydisuyu basin covers an area of $1816.1 \mathrm{~km}^{2}$ that corresponds to almost $13 \%$ surface area of Eskişehir province [4]. Geographical position of the basin within the country, is given in Figure 1.

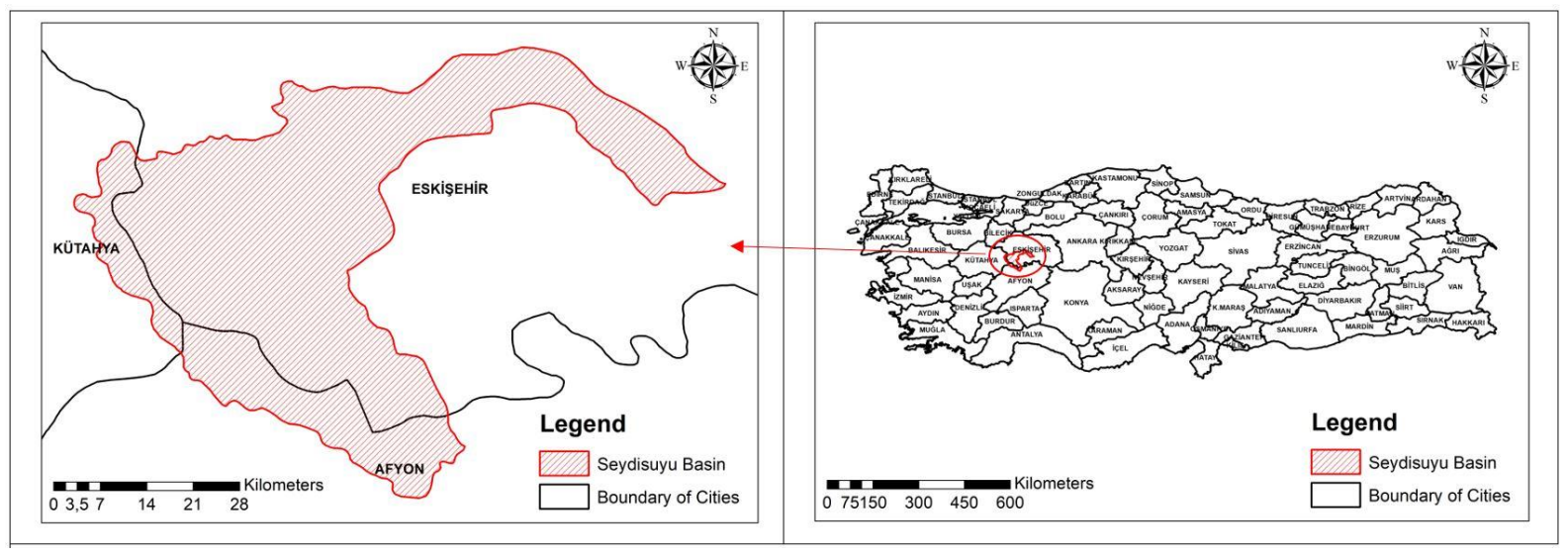

Figure 1. Location of study area

\section{MATERIAL AND METHOD}

\subsection{Material}

Hydrological boundary of Seydisuyu basin and its total area were found using Geographic Information System (GIS). Total approximate area of the basin was estimated as $1816.25 \mathrm{~km}^{2}$. In total, there are two dams found, those were constructed for only irrigation and flood control purposes in the basin. These are Kunduzlar and Çatören dams which is constructed earth-filled dam type, and there is no other water structure in the basin other than the two mentioned dams above.

More than 19 years of monthly flow data discharging from six flow gauging stations in terms $\mathrm{of} \mathrm{m}^{3} / \mathrm{s}$ in the basin, were provided from $3^{\text {rd }}$ Regional Directorate of State Hydraulic Works (DSI). There are six flow gauging stations, found and operated in the basin. Five of them are belonging to State Hydraulic Works (DSI), and the one remaining belongs to General Directorate of Electrical Power Resources Survey and Development Administration (EIE) [5]. Detailed information about the regional location, coordinates, elevation, drainage area and years of measurements of the flow gauging stations are given in Figure 2 and Table 1. 


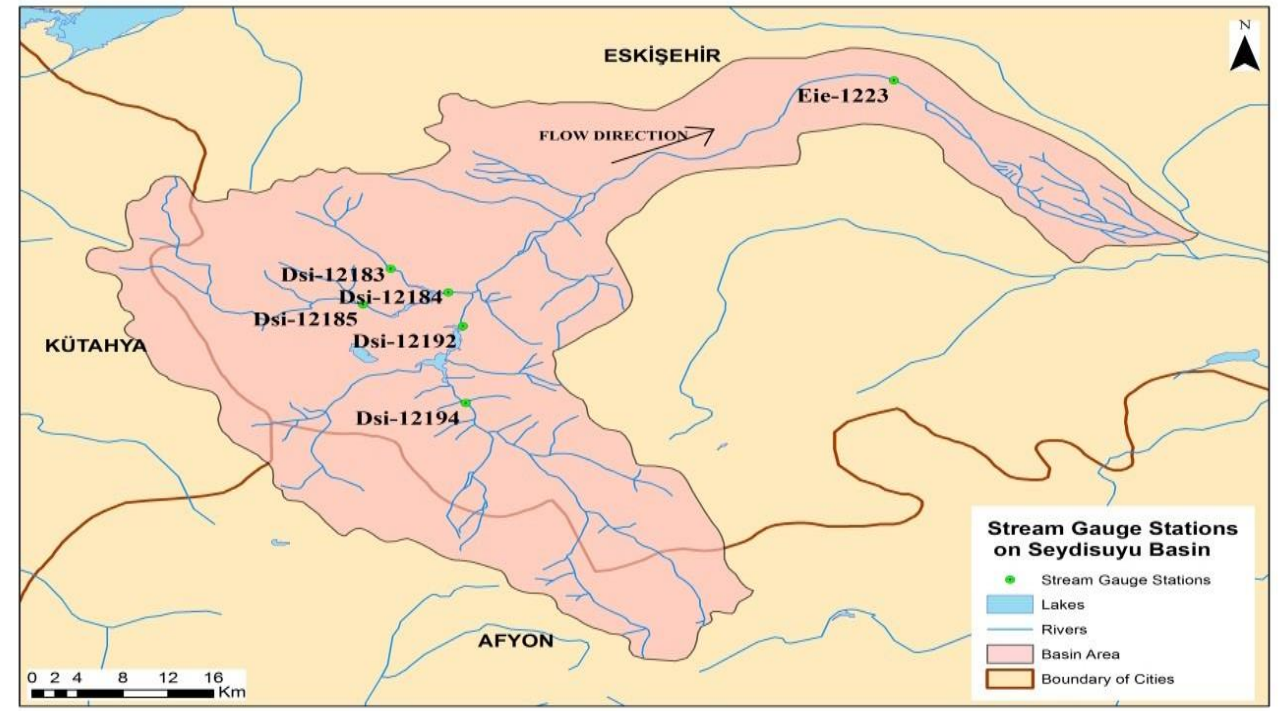

Figure 2. Location and numbers of the flow gauging stations (FGS) located in Seydisuyu basin.

Table 1. Flow gauging stations (FGS) in Seydisuyu Basin

\begin{tabular}{|c|c|c|c|c|c|c|c|}
\hline $\begin{array}{c}\text { FGS- } \\
\text { Station } \\
\text { No } \\
\end{array}$ & Province & Coordinate & Location & $\begin{array}{c}\text { Level } \\
\text { (m) }\end{array}$ & $\begin{array}{c}\text { Drainage } \\
\text { Area } \\
\left(\mathbf{k m}^{2}\right) \\
\end{array}$ & $\begin{array}{c}\text { Years of } \\
\text { Measurement }\end{array}$ & $\begin{array}{c}\text { Number of Years } \\
\text { Measured }\end{array}$ \\
\hline $\begin{array}{c}\text { DSİ- } \\
12183\end{array}$ & Eskişehir & $\begin{array}{l}39.3809 \mathrm{E} \\
30.5274 \mathrm{~N}\end{array}$ & $\begin{array}{l}\text { Upstream } \\
\text { Kunduzlar } \\
\text { Dam }\end{array}$ & 2032 & 94.85 & $1986-2005$ & 19 \\
\hline $\begin{array}{c}\text { DSİ - } \\
12184\end{array}$ & Eskişehir & $\begin{array}{l}39.3575 \mathrm{E} \\
30.5731 \mathrm{~N}\end{array}$ & $\begin{array}{l}\text { Downstream } \\
\text { Kunduzlar } \\
\text { Dam }\end{array}$ & 1857 & 406 & $1986-2005$ & 19 \\
\hline $\begin{array}{c}\text { DSİ- } \\
12185\end{array}$ & Eskişehir & $\begin{array}{l}39.3453 \mathrm{E} \\
30.5053 \mathrm{~N}\end{array}$ & $\begin{array}{l}\text { Upstream } \\
\text { Kunduzlar } \\
\text { Dam }\end{array}$ & 1742 & 218.23 & $1986-2005$ & 19 \\
\hline $\begin{array}{c}\text { DSİ- } \\
12192\end{array}$ & Eskişehir & $\begin{array}{l}38.7268 \mathrm{E} \\
31.0477 \mathrm{~N}\end{array}$ & $\begin{array}{l}\text { Downstream } \\
\text { Çatören } \\
\text { Dam }\end{array}$ & 1005 & 712 & $1988-2005$ & 17 \\
\hline $\begin{array}{c}\text { DSİ- } \\
12194\end{array}$ & Eskişehir & $\begin{array}{l}39.2472 \mathrm{E} \\
30.5868 \mathrm{~N}\end{array}$ & $\begin{array}{l}\text { Upstream } \\
\text { Çatoren } \\
\text { Dam }\end{array}$ & 1045 & 517 & $1990-2005$ & 15 \\
\hline $\begin{array}{l}\text { EIE- } \\
1223\end{array}$ & Eskişehir & $\begin{array}{l}39.5686 \mathrm{E} \\
30.9267 \mathrm{~N}\end{array}$ & $\begin{array}{l}\text { Downstream } \\
\text { Kunduzlar } \\
\text { and Çatören } \\
\text { Dam }\end{array}$ & 895 & 1636.3 & 1953-1997 & 44 \\
\hline
\end{tabular}

One of the crucial issues to be examined in dam planning is, to determine water potential of the basin. In order to estimate water potential of Seydisuyu basin, data of the flow gauging stations in the basin must be examined in a correct manner. The main purpose of this paper is investigation of the hydroelectric power generation over these two small dams mentioned above, which are existing, ready and still in operation on Seydisuyu stream.

Çatören dam was built in 1987 at the downstream point that is located in the upper right area of the Seydisuyu basin. Dam construction was completed in 4 years. Dam was installed downstream of the junction of three steams which are Harami, Ağaçkara and Boyalı streams. At the upstream and 
downstream of this dam there are two current flow gauging stations. These gauging stations are established by State Hydraulic Works (DSI), as named DSİ-1294 and DSİ-1292 respectively (Figure 2). At the upstream side, historical monthly average flow data of 15 years, belonging to DSİ-1294 flow gauging station, were obtained from $3^{\text {rd }}$ Regional Directorate of State Hydraulic works. Also, at the downstream side, historical monthly average flow data of 17 year, released from the dam's reservoir by the bottom outlet to the downstream belonging to DSİ-1292 flow gauging station, were obtained from the same agency. The drainage area of Çatören dam is $712 \mathrm{~km}^{2}$. Areas shown by number (1) and (2) are the sub-basins of the drainage area of Çatören dam (Figure 2, 3).

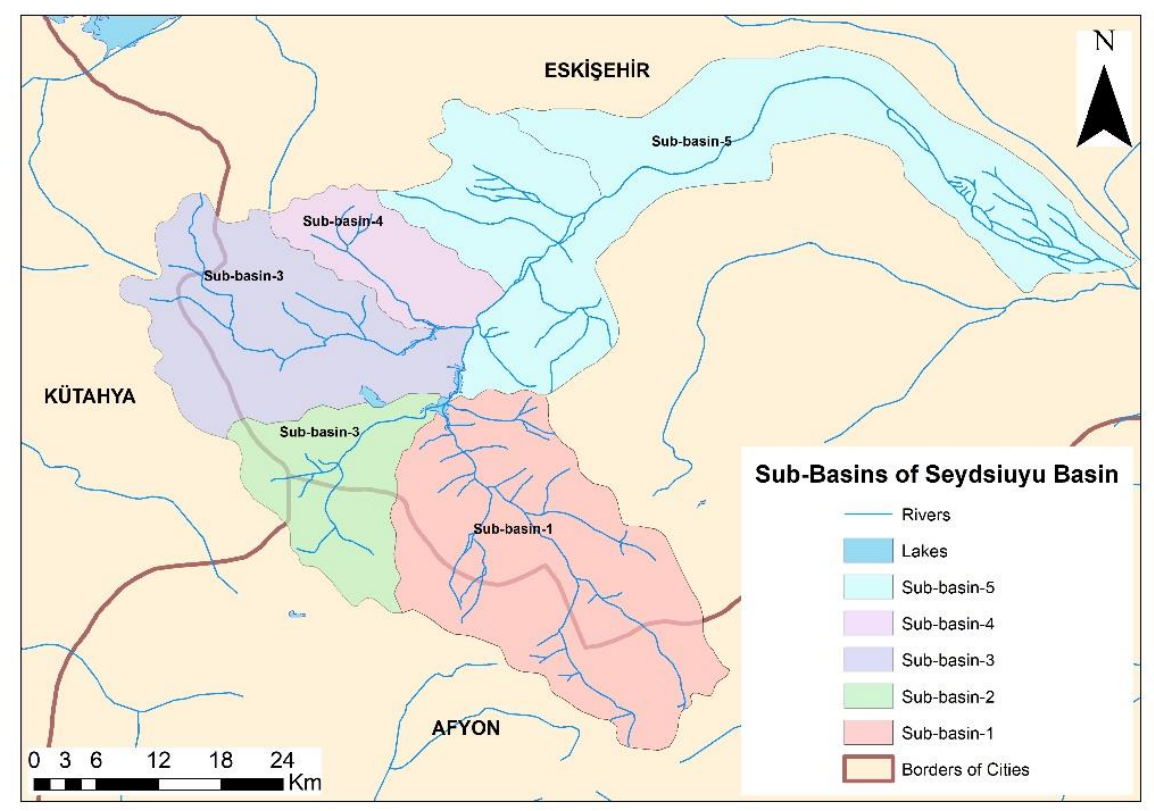

Figure 3. Drainage network and boundaries of Seydisuyu basin and its sub-basins (basin boundaries and drainage networks are generated using 1/25.000 vector maps via GIS program).

Kunduzlar dam was built at the downstream point that is located in the upper left area of the Seydisuyu basin. The construction phase of Kunduzlar Dam took 7 years. Dam was installed after two streams junction which are Keçeliözü and Akin streams. At the upstream and downstream of this dam there are three flow gauging stations. These gauging stations were established by State hydraulic Works (DSI), as named DSI-1285 and DSİ-1283 (at the upstream side), and DSİ-1284 (at the downstream side) of the dam axis. At the upstream side, historical monthly average flow data of 19 years, belonging to DSİ1285 and DSİ-1283 flow gauging stations, were obtained from $3^{\text {rd }}$ Regional Directorate of State Hydraulic works. Also, at the downstream side, historical monthly average flow data of 19 year, released from the dam's reservoir by the bottom outlet to the downstream belonging to DSİ-1284 flow gauging station, was obtained from the same agency (Figure 2, 3). The drainage area of Kunduzlar dam is totally $406 \mathrm{~km}^{2}$.

\subsection{Method}

Flow data discharging from Kunduzlar and Çatören dams were provided from $3^{\text {rd }}$ Regional Directorate of State Hydraulic Works (DSI). Based upon yearly long term (19 years), average monthly flow values of gauging stations (DSİ-184 and DSİ-12192) were calculated. Estimated flow values were analyzed by Simahpp-4 (Simulation Analysis for Hydropower Projects) software. SIMAHPP is a proprietary Windows operating system based software that is used to model and evaluate the feasibility of hydropower projects using hydraulics, financial, and environmental parameters (Figure 5). Initially, it was designed to simulate small hydropower systems up to $10 \mathrm{MW}$, but now, thanks to the newly added 
financial module, it has the capability for simulation of larger hydropower systems with a capacity of higher than $10 \mathrm{MW}$. It provides detailed analysis and results on energy production, economic analysis, environmental impacts, equipment and material selection [6].

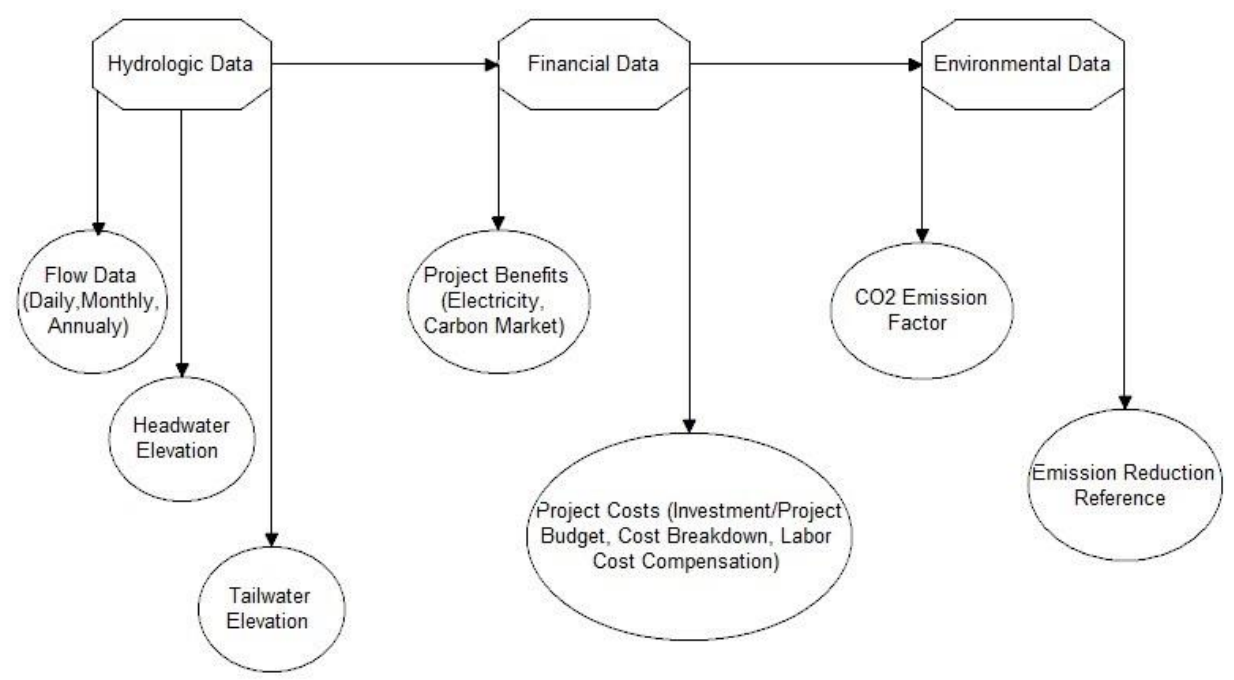

Figure 4. Flow diagram SIMAHPP-4 Professional package program

As a consequence, obtainable energy amount from these dams, and their costs (cost of building) were estimated and analyzed.

\section{RESULT AND DISCUSSION}

Hydroelectric energy amount generable from the Çatören and Kunduzlar Dams being utilized for irrigation purposes was analyzed individually. Hence these dams are currently in operation, they will give accumulated water to their downstream during winter, especially in irrigation season. During flood times and irrigation seasons, it is possible to generate electricity using discharges given by the reservoirs, with installation of an additional turbine generator system in the downstream of the dams.

\subsection{Characteristic Features of Çatören Dam}

Çatören dam has been in operation since 1987 in Seydisuyu basin. Thus, it is a dam with zero construction cost. An appearance of Çatören dam is given in Figure 6. Location and other characteristic features of the dam is given in Table 2 . 


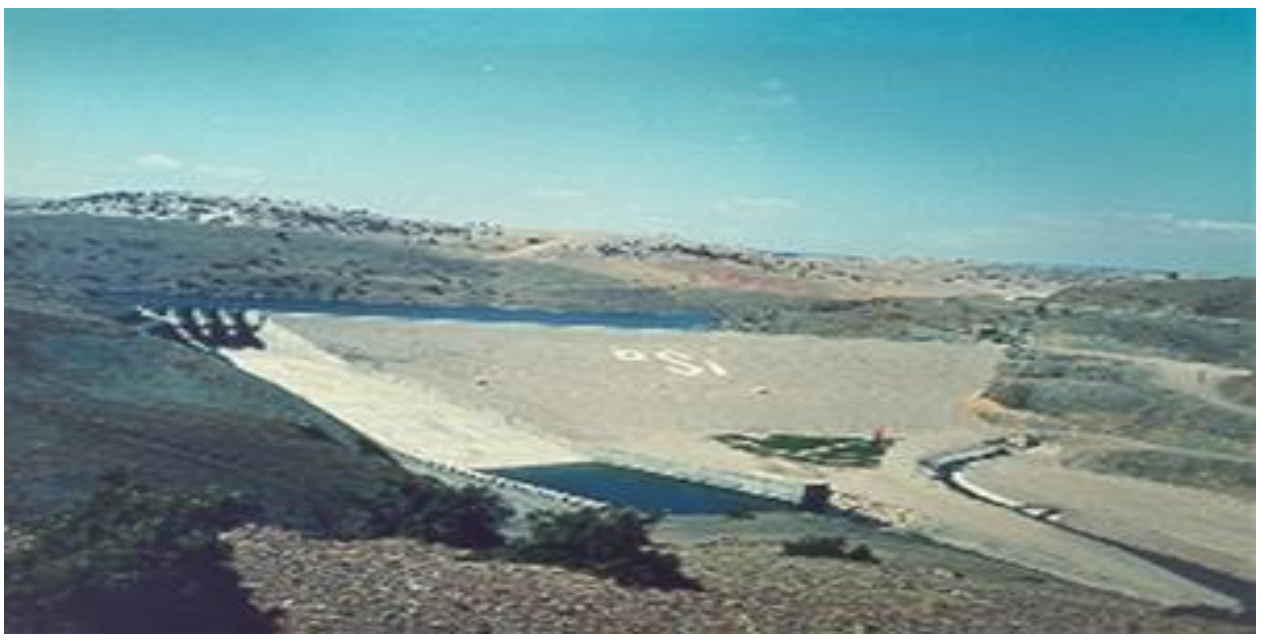

Figure 6. Çatören Dam

Table 2. Characteristic features of Çatören Dam

\begin{tabular}{|c|c|c|c|c|c|c|c|c|}
\hline $\begin{array}{l}\text { Name } \\
\text { of the } \\
\text { dam }\end{array}$ & $\begin{array}{l}\text { Used map name } \\
\text { for location of } \\
\text { the dam }\end{array}$ & $\begin{array}{c}\text { Description of dam } \\
\text { location }\end{array}$ & $\begin{array}{l}\text { Coordinates of } \\
\text { the dam }\end{array}$ & $\begin{array}{l}\text { Crest level } \\
\text { (m) }\end{array}$ & $\begin{array}{c}\text { River } \\
\text { thalweg } \\
\text { level }(\mathrm{m})\end{array}$ & $\begin{array}{l}\text { Dam Height } \\
\text { (m) }\end{array}$ & $\begin{array}{l}\text { Crest Length } \\
\text { (m) }\end{array}$ & $\begin{array}{c}\text { Drainage } \\
\text { Area }\left(\mathbf{k m}^{2}\right)\end{array}$ \\
\hline $\begin{array}{c}\text { Çatören } \\
\text { Dam }\end{array}$ & $\begin{array}{c}\text { Eskisehir J25-a4 } \\
(93-94 / 60-61\end{array}$ & $\begin{array}{l}\text { Dam axis take place: } \\
\text { On the Left, there is } \\
\text { Kayrak hill and } \\
\text { approximately } 2 \mathrm{~km} \\
\text { to the right of } \\
\text { Çatören village, and } \\
2 \mathrm{~km} \text { away from the } \\
\text { south of Numanoluk } \\
\text { area. }\end{array}$ & $\begin{array}{l}30^{0} 34^{\prime} 41.54^{\prime \prime} \mathrm{E} \\
39^{0} 19^{\prime} 34.91^{\prime \prime} \mathrm{N}\end{array}$ & $\begin{array}{c}\text { Crest of the } \\
\text { dam: } 1037.20 \mathrm{~m} \\
\text { Max. level of } \\
\text { the reservoir: } \\
1035.92 \mathrm{~m}\end{array}$ & $1005 \mathrm{~m}$ & $\begin{array}{c}\text { High of the } \\
\text { dam from } \\
\text { thalweg } \\
\text { level: } 32.20 \\
\text { m } \\
\text { High of the } \\
\text { dam from } \\
\text { foundation } \\
\text { level: } 52.20 \mathrm{~m} \\
\text { Upstream } \\
\text { water level: } \\
30.92 \mathrm{~m} \\
\text { High of the } \\
\text { foundation: } \\
20 \mathrm{~m} \text {. }\end{array}$ & $\begin{array}{l}\text { Crest length: } \\
230 \mathrm{~m} \\
\text { Crest width: } \\
5 \mathrm{~m} \\
\text { Base width: } \\
111.60 \mathrm{~m} \\
\text { Upstr: } 2 / 3 \\
\text { Downstr.:2/3 }\end{array}$ & $406 \mathrm{~km}^{2}$ \\
\hline
\end{tabular}

In the data provided from DSİ, discharge measures of tail water in Çatören dam was recorded by station no. DSI 12-192. Monthly average, max., min. flows, and flow duration curve of Çatören dam were given in Figure 7. Average of min flow, average of average flow, and average of max. flow were found as $0.08 \mathrm{~m}^{3} / \mathrm{s}, 1.13 \mathrm{~m}^{3} / \mathrm{s}$ and $4.11 \mathrm{~m}^{3} / \mathrm{s}$ respectively. 
Bakış et al. / Anadolu Univ. J. of Sci. and Technology A-Appl. Sci. and Eng. 19 (2) - 2018

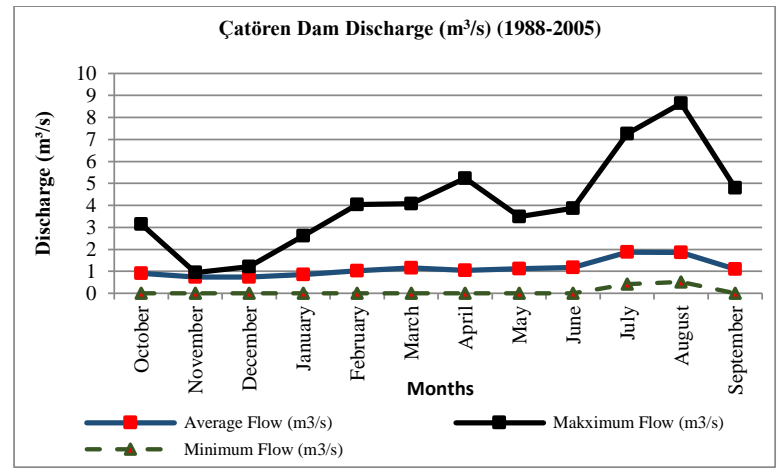

(a)

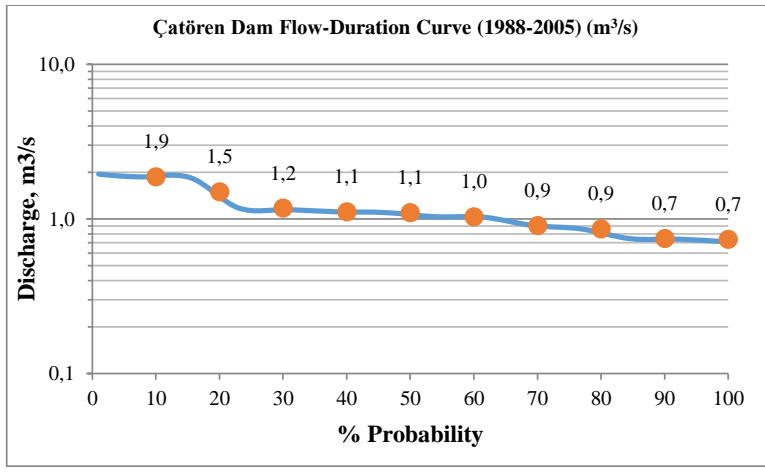

(b)

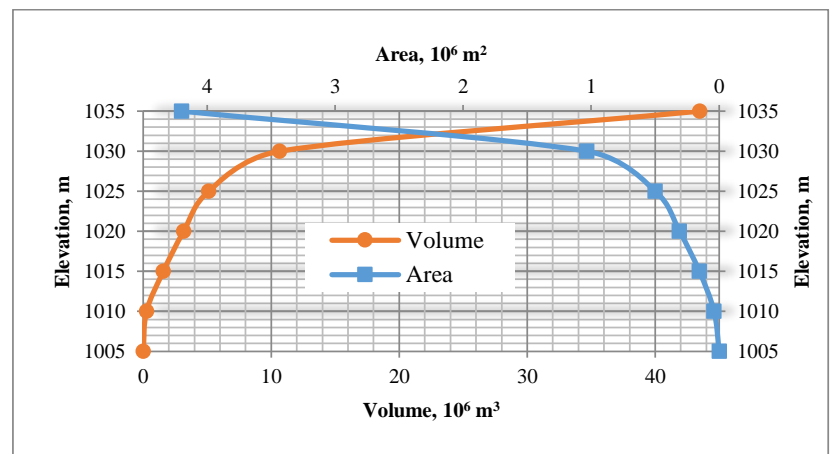

(c)

Figure 7. Çatören Dam discharge, flow-duration curve and volume-area

\subsection{Characteristic Features of Kunduzlar Dam}

Kunduzlar dam has been in operation since 1983 in Seydisuyu basin. Thus, it is a dam with zero construction cost. An appearance of Kunduzlar dam is given in Figure 8. Also, location and other characteristic features of the dam is given in Table 3.

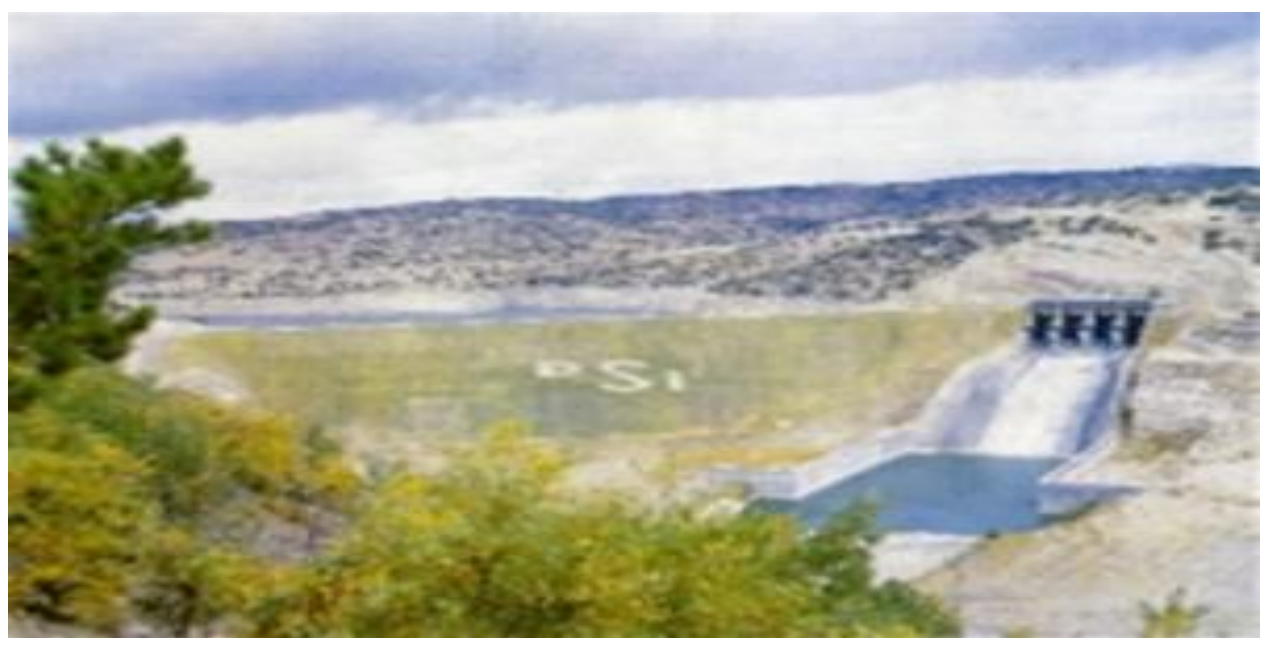

Figure 8. Kunduzlar Dam 
Bakış et al. / Anadolu Univ. J. of Sci. and Technology A-Appl. Sci. and Eng. 19 (2) - 2018

Table 3. Characteristic features of Kunduzlar Dam

\begin{tabular}{|c|c|c|c|c|c|c|c|c|}
\hline $\begin{array}{l}\text { Name of } \\
\text { the dam }\end{array}$ & $\begin{array}{l}\text { Used map } \\
\text { name for } \\
\text { location of } \\
\text { the dam }\end{array}$ & $\begin{array}{l}\text { Description of } \\
\text { dam location }\end{array}$ & $\begin{array}{l}\text { Coordinates of } \\
\text { the dam }\end{array}$ & $\begin{array}{l}\text { Crest level } \\
\text { (m) }\end{array}$ & $\begin{array}{c}\text { River } \\
\text { thalweg } \\
\text { level }(\mathbf{m})\end{array}$ & $\begin{array}{c}\text { Dam } \\
\text { Height (m) }\end{array}$ & $\begin{array}{c}\text { Crest } \\
\text { Length (m) }\end{array}$ & $\begin{array}{c}\text { Drainage } \\
\text { Area } \\
\left(\mathbf{k m}^{2}\right)\end{array}$ \\
\hline $\begin{array}{l}\text { Kunduz } \\
\text { Dam }\end{array}$ & $\begin{array}{c}\text { Eskisehir } \\
\text { J25-a4 } \\
\\
(93-94 / 60-61\end{array}$ & $\begin{array}{c}\text { Dam axis take } \\
\text { place: On the } \\
\text { Yarlgan stream, it } \\
\text { is near the Akın } \\
\text { village }\end{array}$ & $\begin{array}{l}30^{0} 34^{\prime} 6.009^{\prime \prime} \mathrm{E} \\
39^{0} 21^{\prime} 28.24^{\prime \prime} \mathrm{N}\end{array}$ & 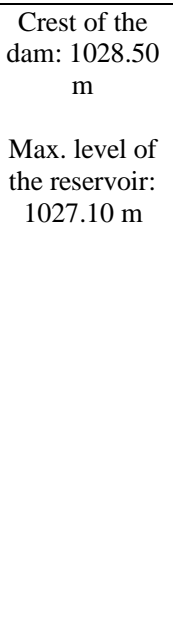 & . & $\begin{array}{l}\text { High of the } \\
\text { dam from } \\
\text { thalweg } \\
\text { level: } \\
28.50 \mathrm{~m} \\
\text { High of the } \\
\text { dam from } \\
\text { foundation } \\
\text { level: } \\
48.50 \mathrm{~m} \\
\text { Upstream } \\
\text { water level: } \\
27.10 \mathrm{~m} \\
\text { High of the } \\
\text { foundation: } \\
20 \mathrm{~m} \text {. }\end{array}$ & $\begin{array}{l}\text { Crest length: } \\
180 \mathrm{~m} \\
\text { Crest width: } \\
5 \mathrm{~m} \\
\text { Base width: } \\
90.5 \mathrm{~m} \\
\text { Upstr:2/3 } \\
\text { Downstr.:2/3 }\end{array}$ & $406 \mathrm{~km}^{2}$ \\
\hline
\end{tabular}

In the data provided from DSİ, discharge measures of tail water in Kunduzlar dam was recorded by station no. DSİ 12-184. Monthly average, max., min. flows, and flow duration curve of Kunduzlar dam were given in Figure 9. Average of min flow, average of average flow, and average of max. flow were found as $0.34 \mathrm{~m}^{3} / \mathrm{s}, 1.34 \mathrm{~m}^{3} / \mathrm{s}$ and $8.85 \mathrm{~m}^{3} / \mathrm{s}$ respectively.

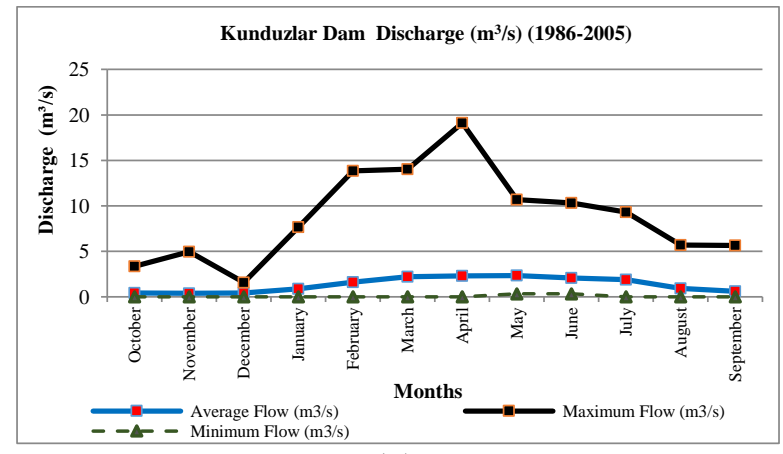

(a)

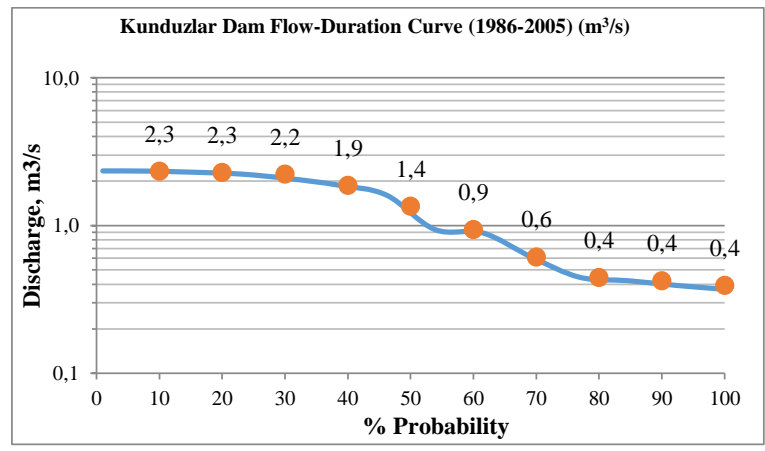

(b)

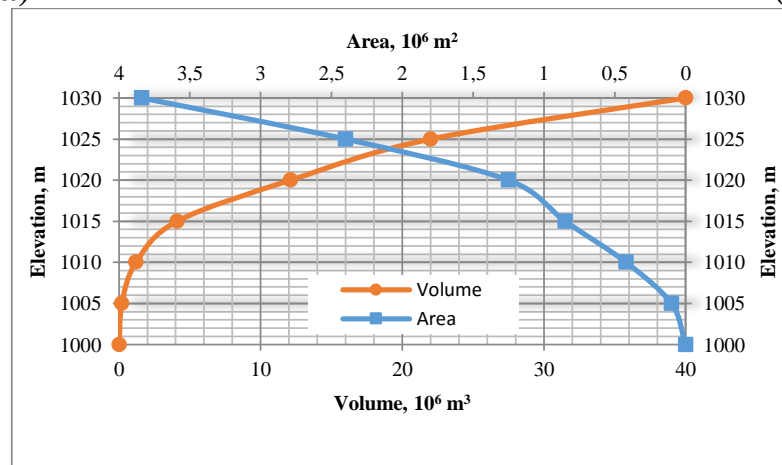

(c)

Figure 9. Kunduzlar Dam discharge, flow-duration curve and volume-area 
Within this study, the hydropower potential of two dams, Kunduzlar and Çatören were calculated and compared using Simahpp-4 software. Dam heights and provided monthly discharges flowing over the axis of Kunduzlar and Çatören dams, were used as input data in Simahpp-4, for the evaluation of hydropower potentials of the dams. The annual amount of electricity to be generated by both dams, their installed capacity, turbine design flow, power production, energy production, investment cost (including civil works, electro-mechanic equipment, infrastructure, labor cost etc.) and self-calculated data, such as payback period are given in Table 4 . The graphical representation of the analysis results was plotted and given in Figure 10.

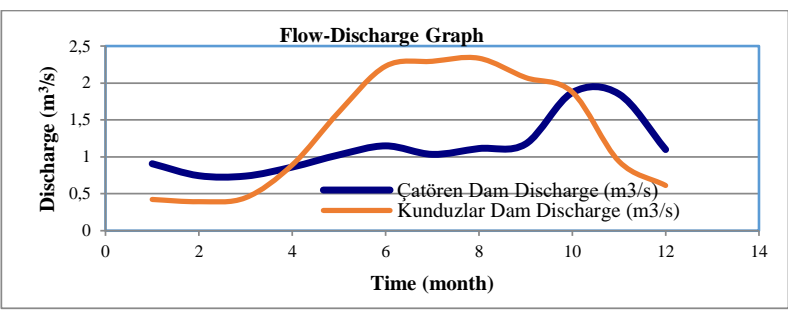

(a)

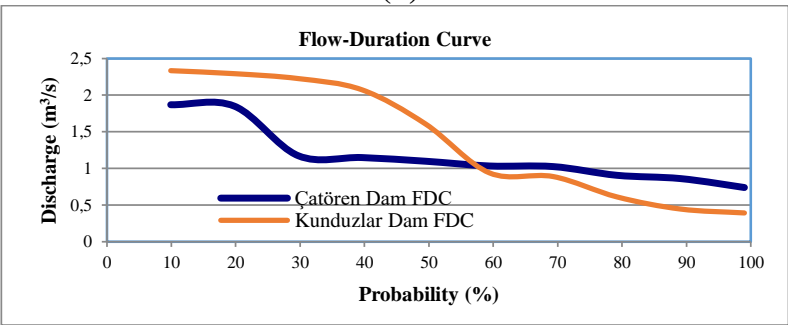

(b)

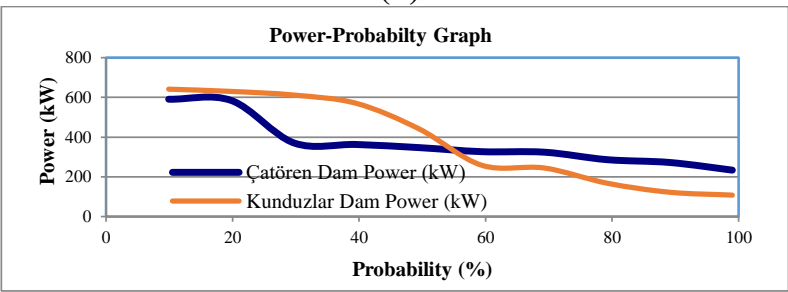

(c)

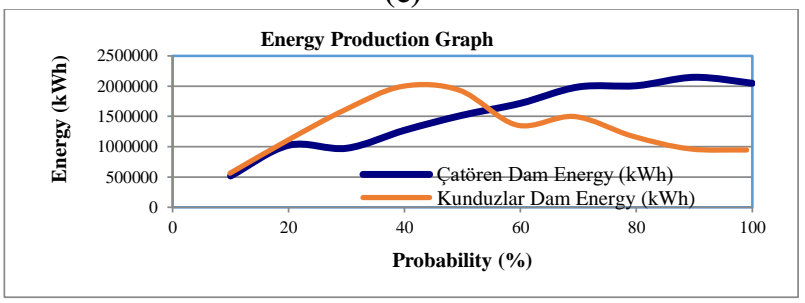

(d)

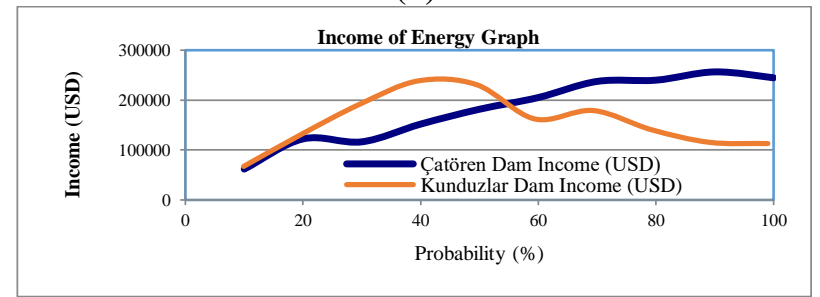

(e)

Figure 5. Graphics of (a) flow-discharge, (b) flow duration, (c) power probability, (d) energy production, (e) energy income of both Kunduzlar and Çatören dams 
Results of Kunduzlar dam that examined the amount of annual electricity to be produced $1.99 \mathrm{GWh}$, total installed capacity of $0.57 \mathrm{MW}$ turbine, design flow rate of $2.07 \mathrm{~m}^{3} / \mathrm{s}$, the annual energy revenue of $0.194 \times 10^{6} \mathrm{USD}$, per $\mathrm{kWh}$ investment the price of $2371.31 \mathrm{USD} / \mathrm{kW}$, and the payback period of 7.48 years. Results of Çatören dam that examined the amount of annual electricity to be produced $2.15 \mathrm{GWh}$, total installed capacity of $0.27 \mathrm{MW}$ turbine, design flow rate of $0.86 \mathrm{~m}^{3} / \mathrm{s}$, the annual energy revenue of $0.21 \times 10^{6} \mathrm{USD}$, per $\mathrm{kWh}$ investment the price of $2597.18 \mathrm{USD} / \mathrm{kW}$, and the payback period of 3.50 years. In addition, Emission reduction results which appear in the program software $\left[\left(\mathrm{CO}_{2} /\right.\right.$ year)-Coal $\left(\mathrm{CO}_{2} /\right.$ year)-Gas $\left(\mathrm{CO}_{2} /\right.$ year)-fuel (or oil)] are closely related to the carbon markets. The carbon market is a market to sell and buy shares of greenhouse gases in order for countries to reach their emission targets. Accordingly, in this study, it is observed that [7].

- To produce $1.99 \mathrm{GWh} /$ year power (Estimated hydropower potential of Kunduzlar dam), the amount of coal required to generate this amount of electricity in a year will lead to 1197.71 tons of $\mathrm{CO}_{2}$ emissions will be released into the atmosphere. If gas is used, 399.24 tons of $\mathrm{CO}_{2}$ emissions will be released and, if oil is used, 638.78 tons of $\mathrm{CO}_{2}$ to be released into the atmosphere. The amount of these oscillations of the carbon market will cost 7452.41 USD per year.

- To produce $2.15 \mathrm{GWh} /$ year power (Estimated hydropower potential of the Çatören dam), the amount of coal required to generate this amount of electricity in a year will lead to 1288.04 tons of $\mathrm{CO}_{2}$ emissions will be released into the atmosphere. If gas is used, 429.35 tons of $\mathrm{CO}_{2}$ emissions will be released and, if oil is used, 686.86 tons of $\mathrm{CO}_{2}$ will be released into the atmosphere. The amount of these oscillations of the carbon market will cost 8014.48 USD per year.

Consequently, a hydroelectric power plant plays a basic role in the environment and thereby presents an important contribution for global warming decrease.

Table 2. Hydroelectric characteristics of the dams analyzed by SIMAHPP-4

\begin{tabular}{lll} 
Parameters & Kunduzlar Dam & Çatören Dam \\
\hline Net Head $(\mathrm{m})$ & 28.00 & 32.20 \\
Time of Operation $(\%)$ & 40 & 90 \\
Design Flow $\left(\mathrm{m}^{3} / \mathrm{s}\right)$ & 2.07 & 0.86 \\
Power Production $(\mathrm{kW})$ & 569.69 & 272.29 \\
Energy Production $(\mathrm{kWh} / \mathrm{year})$ & 1996180.87 & 2146736.65 \\
Energy Revenue $(\mathrm{USD} / \mathrm{Year})$ & 194230.62 & 208879.87 \\
Emission Reduction $\left(\mathrm{tCO}_{2} /\right.$ Year-Coal) & 1197.71 & 1288.04 \\
Emission Reduction $\left(\mathrm{tCO}_{2} /\right.$ Year-Gas) & 399.24 & 429.35 \\
Emission Reduction $\left(\mathrm{tCO}_{2} /\right.$ Year-Fuel) & 638.78 & 686.96 \\
Carbon Market (USD/Year-Mean) & 7452.41 & 8014.48 \\
Investment Cost/kW (USD/kW) & 2371.31 & 2597.18 \\
Payback Period (Years) & 7.48 & 3.50 \\
Suggested Turbine Type & Francis & Francis
\end{tabular}

\section{CONCLUSION}

To fulfil the rising need of energy, significance of renewable energy sources has increased still more, along with the development of industry and technology. Evaluation of hydroelectric energy from renewable sources is a pre-requirement in our country that is quite rich in terms of water resources. State Hydraulic Works (DSI) is planning numerous hydroelectric power plant in this regard. High investment costs that come in view on planning to construct new hydroelectric power plants are forcing economy of this country.

Intended remarkable matter within this study is installation of hydroelectric power plants over the existing dams (irrigation, flood control and water supply) those are holding proper heads and do not 
need a higher investment costs. By this way, there will be an opportunity to generate hydroelectric energy from already constructed dams. In this research, two existing dams in Seydisuyu basin (Kunduzlar and Çatören dams) were investigated as a case event. These dams were constructed for the purpose to satisfy the need of irrigation water in the basin. But they are not producing electricity. However, assuming a plan of hydroelectric power plant on each of these dams, amount of energy that might be generated from each dam were estimated. Doing this type of researches play an important role for a better evaluation, in terms of water resources.

\section{ACKNOWLEDGEMENTS}

This study has been supported within the context of project no. 1606F626 accepted by Commission of Scientific Research Projects of Anadolu University. In addition, we would like to thank General Directorate of State Hydraulic Works (DSI) for their support.

\section{REFERENCES}

[1] Çabuk SN, Bakiş R, Göncü S, Gümüşlüoğlu E and Çabuk A. Investigation of Hydropower Potential of Şemdinli River Basin, World Appl. Sci. J., vol. 32, no. 8, pp. 1731-1737, 2014.

[2] Cabuk SN, Bakis R, Goncu S, Gumusluoglu E and Cabuk A. Investigation of Hydroelectric Energy Potential of the Zab River Basin Using Geographic Information Systems and Remote Sensing Methods, J. Renew. Sustain. Energy, vol. 5, no. 6, 2013.

[3] World Energy Council, World Energy Resources Hydropower, 2016.

[4] Bayazıt Y, Bakış, R, Koç C. Mapping Distribution of Precipitation Temperature and Evaporation in Seydisuyu Basin with the Help of Distance Related Estimation Methods, Journal of Geographic Information System, Vol:08, No:02, 224-237 pp., doi:10.4236/jgis.2016.82020., 2016.

[5] Devlet Meteoroloji İşleri Genel Müdürlüğü (DMI) (2011) Ankara. http://www.dmi.gov.tr/index.aspx\#sfU

[6] SIMAHPP., Simulation for Hydropower Optimization and Project Feasibility, Hydroexpert, URL: http://hydroxpert.com/simahpp-professional-hydropower-software., 2016.

[7] Koç C, Bayazıt Y, Bakış R. A Study on Determining the Hydropower Potential of Çine Dam in Turkey, Computational Water, Energy and Environmental Engineering, Vol:05, No:02, 79-85 pp. doi:10.4236/cweee.2016.52008., 2016. 